\title{
Efektivitas Model Discovery Learning terhadap Keterampilan Menulis Surat Dinas Siswa Kelas VII SMP Negeri B Srikaton
}

\author{
M. Syahrun Effendi \\ (corresponding author) \\ Program Studi Pendidikan Bahasa dan Sastra Indonesia \\ STKIP PGRI Lubuklinggau \\ Email: syahrunsyahrun788@gmail.com \\ Eko Saputra \\ Program Studi Pendidikan Bahasa dan Sastra Indonesia \\ STKIP PGRI Lubuklinggau \\ Email: ekosaputra310817@gmail.com
}

\begin{abstract}
APA Citation: Effendi, M. S. \& Saputra, E. (2021). Efektivitas Model Discovery Learning terhadap Keterampilan Menulis Surat Dinas Siswa Kelas VII SMP Negeri B Srikaton. Silampari Bisa: Jurnal Penelitian Pendidikan Bahasa Indonesia, Daerah, dan Asing, 4(2), 306-316. https://doi.org/10.31540/silamparibisa.v4i2.1440
\end{abstract}

\begin{abstract}
Abstrak
Penelitian ini bertujuan untuk mengetahui apakah model discovery learning secara signifikan efektif terhadap keterampilan menulis surat dinas siswa kelas VII SMP Negeri B Srikaton. Metode yang digunakan dalam penelitian ini adalah eksperimen semu dengan desain one group pretest-posttest. Populasi penelitian adalah seluruh siswa kelas VII SMP Negeri B Srikaton tahun pelajaran 2020/2021 yang berjumlah 236 siswa. Satu kelas ditetapkan sebagai sampel yang ditetapkan dengan teknik simple random sampling yaitu kelas VII.6 yang berjumlah 30 siswa sebagai kelas eksperimen. Pengumpulan data menggunakan teknik tes dalam bentuk tes menulis surat dinas. Teknik analisis data dilakukan dengan menggunakan uji t. Hasil penelitian membuktikan bahwa model pembelajaran discovery learning secara signifikan efektif terhadap keterampilan menulis surat dinas siswa kelas VII SMP Negeri B Srikaton. Hal ini dibuktikan dengan hasil thitung 6,68 lebih besar tabel 1,699 pada taraf signifikan $5 \%$, dengan demikian hipotesis alternatif $(\mathrm{Ha})$ penelitian ini diterima.
\end{abstract}

Kata kunci: efektivitas, model pembelajaran discovery learning, keterampilan menulis surat dinas 


\title{
The Effectiveness of Discovery Learning Model on Writing Service Letter Skills Students of Class VII SMP Negeri B Srikaton
}

\begin{abstract}
This study aims to determine whether the discovery learning model is significantly effective on the writing skills of seventh grade students of SMP Negeri B Srikaton. The method used in this study was a quasi-experimental with a one group pretest-posttest design. The study population was all 7th grade students of SMP Negeri B Srikaton for the 2020/2021 academic year, totaling 236 students. One class is defined as the sample determined by the simple technique random sampling, namely class VII.6, totaling 30 students as the experimental class. Collecting data using a test technique in the form of an official letter writing test. The data analysis technique was carried out using the "t test. The results of the study prove that the discovery learning model is significantly effective on the writing skills of seventh grade students of SMP Negeri B Srikaton. This is evidenced by the results of tcount 6.68 greater than ttable 1.699 at a significant level of $5 \%$, thus the alternative hypothesis $(\mathrm{Ha})$ of this study is accepted.
\end{abstract}

Keywords: effectiveness, discovery learning model, official letter writing skills

\section{A. Pendahuluan}

Pembelajaran menulis surat dinas merupakan salah satu aktivitas pembelajaran yang urgen untuk menjadikan siswa terampil berkomunikasi secara tertulis dalam situasi formal dan kadinasan. Pembelajaran ini tidak hanya melatih keterampilan siswa dalam penerapan penguasaan struktur dan isi surat, tetapi juga melatih keterampilan dalam menerapkan penggunaan bahasa resmi dalam konteks formal. Keterampilan menulis surat dinas penting juga dikuasai siswa, karena proses pembelajaran menulis surat dinas merupakan bagian pembelajaran dalam kurikulum 2013 yang di antaranya tercantum dalam KD 4.14 kelas VII semester genap silabus bahasa Indonesia. Oleh karena itu, materi pembelajaran surat dinas harus diajarkan kepada siswa serta ditangani secara sungguh-sungguh sehingga pembelajaran surat dinas dapat terlaksana dengan baik dan mencapai hasil yang optimal.

Surat dinas merupakan surat yang ditulis dalam situasi formal dan untuk kepentingan formal (Permatasari, 2019). Surat dinas bisa ditulis oleh pribadi maupun atas nama suatu lembaga (Harsiati, dkk. 2017:248). Menurut Ahyana (2020:3) surat dinas adalah bentuk komunikasi tertulis yang menggunakan bahasa baku dari suatu pihak kepada pihak lain yang menyangkut kedinasan atau organisasi dan hanya dibuat oleh pemerintah. Syam, dkk. (2019:20) menjelaskan surat dinas adalah surat yang berisi masalah kedinasan atau bisnis tertentu yang bersifat resmi. Dalam proses pembuatan surat dinas harus memperhatikan aturan penulisan surat resmi, seperti aturan tata bahasa dan ejaan yang baik dan benar. Maka dari itu, sebelum menulis surat penulis harus mempertimbangkan dengan baik susunan kalimat, pilihan kata atau diksi dan ejaan yang dapat memperjelas maksud surat. Selain itu, penulis surat harus menghindari pemakaian diksi yang kurang tepat serta memperhatikan pedoman penulisan surat. Kesalahan dalam berkomunikasi melalui surat dapat dihindari dengan menulis pesan secara jelas

Silampari Bisa: Jurnal Penelitian Pendidikan Bahasa Indonesia, Daerah, dan Asing Vol. 4, No. 2, 2021 


\section{Syahrun Effendi, Eko Saputra}

Efektivitas Model Discovery Learning terhadap Keterampilan Menulis Surat Dinas Siswa Kelas VII SMP Negeri B Srikaton

serta diungkapkan dengan benar. Penggunaan bahasa yang tepat dan benar dapat membantu penerima surat memahami maksud dari pengirim surat, serta memiliki pengertian yang sama.

Harsiati, dkk. (2017:248) menjelaskan pula, bahasa yang digunakan pada surat dinas lebih mudah pahami dibandingkan surat pribadi. Surat dinas atau surat resmi tidak menggunakan bahasa yang berbunga-bunga atau bahasa kiasan. Bahasa surat dinas atau surat resmi singkat dan jelas, serta berpola tetap. Berdasarkan informasi awal yang didapat dari hasil wawancara dengan salah satu guru bahasa Indonesia di sekolah SMP B Srikaton pada tanggal 15 Maret 2021, bahwa siswa kelas VII SMP B Srikaton kurang mampu menulis khususnya dalam memilih dan menyusun kata dengan tepat untuk menyampaikan ide dalam menulis surat dinas. Nilai rata-rata siswa untuk materi pelajaran menulis belum tuntas dan masih di bawah nilai KKM yang ditetapkan sekolah. KKM Mata Pelajaran Bahasa Indonesia di SMP B Srikaton adalah 68. Dari jumlah siswa kelas VII SMP B Srikaton 236 siswa yang tuntas mencapai KKM hanya sekitar $50 \%$ saja.

Secara umum siswa kurang aktif dan siswa juga terasa bosan karena metode yang digunakan adalah metode penugasan. Siswa kurang antusias untuk berpikir kritis, terlihat jenuh, pada saat pengumpulan tugas sering kali terlambat dan tidak tepat waktu, hanya beberapa siswa saja yang rajin dan benar-benar ingin belajar. Hal ini merupakan akibat penggunaan model pembelajaran yang diterapkan guru kurang tepat, sehingga tujuan pembelajaran tidak tercapai dengan optimal. Model (metode) pembelajaran yang digunakan atau diterapkan guru kurang tepat merupakan faktor yang menyebabkan kurangnya kemampuan menulis siswa (Effendi, 2018:4). Oleh karena itu, diperlukan model pembelajaran yang dapat mengembangkan kemampuan dan semangat siswa, sehingga siswa menjadi lebih aktif dan kreatif dalam pembelajaran. Untuk itu, peneliti melakukan penelitian mengenai keterampilan menulis surat dinas siswa kelas VII SMP Negeri B Srikaton. Keterampilan menulis surat dinas siswa penting untuk dideskripsikan, karena merupakan KD yang terdapat dalam kurikulum dan materi surat dinas penting diajarkan kepada siswa serta harus ditangani secara sungguh-sungguh sehingga terlaksana dan berhasil dengan baik.

Dalam melaksanakan pembelajaran surat dinas seharusnya tidak sekedar terfokus pada pengajaran tentang pengetahuan struktur surat, diksi atau tatabahasa dan memenuhi tugas saja tanpa memperhatikan keterampilan yang dimiliki siswa (Nurgiyantoro, 2012:437). Pembelajaran yang dilakukan seharusnya memberi dampak dan meningkatkan keterampilan siswa. Untuk itu, perlu diterapkan suatu teknik yang mampu meningkatkan keterampilan siswa menulis surat dinas dengan baik serta suasana belajar yang tidak membuat siswa menjadi jenuh. Salah satu teknik yang dapat membantu siswa dalam pembelajaran menulis surat dinas dengan menerapkan model discovery learning.

Model discovery learning adalah model mengajar yang mengatur pengajaran sedemikian rupa sehingga anak memperoleh pengetahuan dengan cara ditemukan sendiri oleh siswa (Pratiwi, 2020). Dalam pembelajaran discovery learning kegiatan atau pembelajaran yang dirancang sedemikian rupa sehingga siswa dapat

Silampari Bisa: Jurnal Penelitian Pendidikan Bahasa Indonesia, Daerah, dan Asing Vol. 4, No. 2, 2021 


\section{Syahrun Effendi, Eko Saputra}

Efektivitas Model Discovery Learning terhadap Keterampilan Menulis Surat Dinas Siswa Kelas VII SMP Negeri B Srikaton

menemukan konsep-konsep dan prinsip-prinsip melalui mental siswa sendiri (Azhari, 2015:15). Menurut Rosarina, dkk. (2016:374) model discovery learning adalah model pembelajaran yang menitikberatkan pada kemampuan mental dan fisik para siswa yang akan memperkuat semangat dan konsentrasi mereka dalam melakukan kegiatan pembelajaran.

Suprihatiningrum (2013:242) menjelaskan bahwa melalui pembelajaran discovery learning diharapkan siswa terlibat dalam penyelidikan suatu hubungan, mengumpulkan data, dan menggunakannya untuk menemukan hukum atau prinsip yang berlaku pada kejadian tersebut. Pembelajaran discovery learning disusun dengan asumsi bahwa observasi yang teliti dan dilakukan dengan hati-hati serta mencari bentuk atau pola dari temuannya akan mengarahkan siswa kepada penemuan hukum-hukum atau prinsip-prinsip. Model pembelajaran discovery learning banyak memberikan kesempatan bagi siswa untuk terlibat langsung dalam kegiatan belajar, kegiatan seperti itu akan lebih menuntut siswa menjadi lebih aktif dan kreatif.

Langkah-langkah model discovery learning menurut Sinambela dalam Yuliana (2018:22-23) terbagi menjadi enam, yakni: (1) simulation atau pemberian masalah kepada siswa di awal yang kemudian membuat siswa penasaran untuk memecahkan masalah tersebut; (2) mengidentifikasi masalah, yaitu guru memberikan kesempatan kepada siswa untuk menidentifikasi masalah yang telah diberikan; (3) melakukan pengumpulan data terkait masalah tersebut; (4) mengolah data atau informasi yang telah didapatkan oleh siswa; (5) siswa membuktikan benar atau tidaknya informasi yang telah ditemukan; (6) siswa menarik kesimpulan dari masalah yang telah diselesaikannya. Selain itu, langkah-langkah model discovery learning dapat dilakukan menurut Salmi (2019:6) sebagai berikut: (1) guru memberi stimulus kepada siswa; (2) mengidentifikasi permasalahan yang relevan dengan materi pelajaran, merumuskan masalah lalu menentukan jawaban sementara (hipotesis); (3) membagi siswa menjadi beberapa kelompok untuk melakukan diskusi; (4) guru memfasilitasi siswa dalam kegiatan pengumpulan data kemudian mengolahnya sebagai bukti jawaban sementara: (5) membimbing siswa menarik kesimpilan berdasarkan pengamatannya; (6) membimbing siswa untuk mengomunikasikan hasil jawabannya. Dengan demikian, model discovery learning diterapkan dengan langkah-langkah sebagai berikut, pertama-pertama guru memberikan stimulus kepada siswa dengan cara menyampaikan masalah untuk dipecahkan. Kemudian guru memberikan kesempatan kepada siswa untuk mengidentifikasi masalah dan membentuk kelompok kecil untuk berdiskusi. Selanjutnya, guru memfasilitasi siswa dalam kegiatan pengumpulan dan mengolah data serta menarik kesimpulan berdasarkan hasil pengamatan. Terakhir, guru memberi kesempatan siswa untuk mempresentasikan hasilnya dan mengadakan evaluasi hasil kegiatan.

Adapun surat dinas merupakan salah satu alat komunikasi tertulis yang digunakan untuk menyampaikan informasi tentang kedinasan, dibuat oleh pejabat organisasi/instansi pemerintah. Surat dinas dibuat oleh seseorang dalam kedudukannya sebagai pejabat instansi, pemerintah, maka surat dinas itu disebut juga surat jabatan. Surat dinas harus menggunakan bahasa Indonesia yang sesuai

Silampari Bisa: Jurnal Penelitian Pendidikan Bahasa Indonesia, Daerah, dan Asing Vol. 4, No. 2, 2021 


\section{Syahrun Effendi, Eko Saputra}

Efektivitas Model Discovery Learning terhadap Keterampilan Menulis Surat Dinas Siswa Kelas VII SMP Negeri B Srikaton

dengan kaidah baku (Wiguna dkk., 2016:96). Sedangkan, ciri-ciri surat dinas adalah: (1) menggunakan kop surat apabila dikeluarkan organisasi; (2) ada nomor surat, lampiran, dan perihal; (3) menggunakan salam pembuka dan penutup yang lazim; (4) menggunakan bahasa yang resmi; dan (5) menggunakan cap atau stempel dari lembaga resmi (Wiguno \& Jaja, 2019).

\section{B. Metode Penelitian}

Penelitian ini menggunakan metode eksperimen semu dengan desain one group pretest-posttest. Dalam penelitian hanya satu kelompok sampel yang digunakan sebagai kelompok eksperimen, yaitu kelas VII. 6. Kelas ini diberikan perlakuan pembelajaran dengan menggunakan model discovery learning. Sebelum diberikan perlakuan terlebih dahulu dilaksanakankan pre test dan setelah diberi perkaluan dilaksanakan post test. Desain penelitian ini seperti berikut.

Tabel 1. Desain Penelitian

\begin{tabular}{cccc}
\hline Group & Pre-test & Treatment & Posttest \\
\hline $\mathrm{A}$ & $\mathrm{O}_{1}$ & $\mathrm{X}$ & $\mathrm{O}_{2}$ \\
\hline & & & (Sumber: Arikunto, 2010)
\end{tabular}

Keterangan:
A : Kelompok sampel acak
$\mathrm{O}_{1}, \mathrm{O}_{2}$ : Pre-test dan Posttest
$X \quad$ : Perlakuan dengan penerapan model discovery learning

Penelitian dilaksanakan di SMP Negeri B Srikaton. Waktu pelaksanaannya 21 April - 21 Mei 2021 dengan populasi seluruh siswa kelas VII SMP Negeri B Srikaton tahun 2020/2021 yang berjumlah 236 siswa yang terdiri 7 kelas dan kelas VII.6 yang berjumlah 30 siswa ditetapkan sebagai kelas eksperimen dengan menggunakan teknik simple random sampling.

Dalam penelitian ini menggunakan beberapa teknik untuk penganalisisan data yakni melakukan uji validitas (isi) tes. Tes yang digunakan berupa tes esai atau uraian, yaitu tes menulis surat dinas. Tes dilaksanakan sebelum pembelajaran (pre test) untuk mengetahui kemampuan siswa sebelum diterapkan model pembelajaran, selanjutnya dilakukan post test setelah pembelajaran untuk mengetahui peningkatan nilai siswa setelah diterapkan model discovery learning. Selain uji validitas, penelitian ini menggunakan uji t pada taraf signifikan $5 \%$ untuk menganalisis data. Sebelum uji t, dilakukan terlebih dahulu uji prasayarat yakni uji normalitas data. Uji t dilakukan untuk mengetahui efektivitas penerapan model discovery learning. 


\section{Syahrun Effendi, Eko Saputra}

Efektivitas Model Discovery Learning terhadap Keterampilan Menulis Surat Dinas Siswa Kelas VII SMP Negeri B Srikaton

\section{Hasil Penelitian dan Pembahasan \\ 1. Hasil Penelitian}

Penelitian ini dilaksanakan dari 21 April sampai dengan 21 Mei 2021 di kelas

VII.6 SMP Negeri B Srikaton Musi Rawas, Sumatera Selatan. Pelaksanaan penelitian dilakukan oleh peneliti sesuai jadwal yang telah disepakati dengan pihak sekolah. Model pembelajaran yang diterapkan ialah model discovery learning dengan materi menulis surat dinas. Sebelum pelaksanaaan penelitian dilakukan kegiatan pre test untuk mengetahui kemampuan awal siswa. Sedangkan post test untuk mengetahui efektivitas model discovery learning.

Pelaksanaan pre test diperlukan untuk mengetahui kemampuan awal siswa pada materi menulis surat dinas. Kemampuan pre test adalah kemampuan yang dimiliki siswa sebelum dilaksanakan pembelajaran. Setelah diadakan pre test dan mengetahui kemampuan awal siswa, dilaksanakan treatment yakni pembelajaran pada kelas eksperimen dengan menerapkan model discovery learning. Kemudian, pada tahap akhir penelitian diadakan kegiatan post test untuk mengetahui apakah model discovery learning efektif terhadap keterampilan menulis surat dinas. Hasil perhitungan pre test seperti pada tabel 2 berikut.

Tabel 2. Rekapitulasi Perhitungan Data Tes Awal (Pre Test)

\begin{tabular}{lc}
\hline Kategori & Keterangan \\
\hline Jumlah Siswa & 30 \\
\hline Rata-Rata Nilai & 57,10 \\
\hline Simpangan Baku & 7,67 \\
\hline Jumlah Siswa yang Tuntas & 4 siswa $(13,33 \%)$ \\
\hline Jumlah Siswa yang Tidak Tuntas & 26 siswa $(86,67 \%)$ \\
\hline
\end{tabular}

Dari tabel di atas dapat diketahui bahwa nilai rata-rata siswa 57,10 . Hasil pre test hanya 4 siswa yang tuntas belajar (13,33\%), sedangkan yang tidak tuntas 26 siswa $(86,67 \%)$ dan simpangan baku pada pre-test 7,67. Dengan demikian, dapat disimpulkan bahwa keterampilan menulis surat dinas siswa masih tergolong rendah karena siswa yang tuntas hanya 4 siswa $(13,33) \%$.

Setelah kemampuan awal siswa diketahui dilanjutkan dengan pembelajaran dengan menerapkan model discovery learning terhadap kelas sampel penelitian. Pada akhir kegiatan pembelajaran dilakukan kegiatan tes akhir (post test) untuk mengetahui kemampuan akhir siswa setelah diterapkan model discovery learning. Hasil tes akhir yang diperoleh seperti pada tebel 3 berikut.

Tabel 3. Rekapitulasi Perhitungan Data Tes Akhir (Post Test)

\begin{tabular}{lc}
\hline Kategori & Keterangan \\
\hline Jumlah Siswa & 30 \\
\hline Rata-Rata Nilai & 70,55 \\
\hline Simpangan Baku & 7,53 \\
Jumlah siswa yang tuntas & 18 siswa $(60 \%)$ \\
\hline Jumlah siswa yang tidak tuntas & 12 siswa $(40 \%)$ \\
\hline
\end{tabular}

Silampari Bisa: Jurnal Penelitian Pendidikan Bahasa Indonesia, Daerah, dan Asing Vol. 4, No. 2, 2021 


\section{Syahrun Effendi, Eko Saputra}

Efektivitas Model Discovery Learning terhadap Keterampilan Menulis Surat Dinas Siswa Kelas VII SMP Negeri B Srikaton

Berdasarkan tabel 3 di atas dapat diketahui bahwa nilai rata-rata siswa 70,55. Hasil post test yang tuntas sebanyak 18 siswa (60\%) yang tidak tuntas 12 siswa (40\%), simpangan baku pada post test 7,53. Dengan demikian, dapat diketahui bahwa keterampilan menulis surat dinas siswa tergolong baik karena siswa yang tuntas berjumlah 18 siswa $(60 \%)$ dengan nilai rata-rata 70,55.

Berdasarkan tabel 2 dan 3 di atas, jika dibandingkan data tes awal dengan data pada tes akhir terdapat perbedaan hasil belajar siswa sebesar 13,45. Pada tes awal nilai rata-rata yang diperoleh sebesar 57,10, setelah dilakukan pembelajaran dengan model discovery learning dan tes akhir nilai rata-rata yang diperoleh siswa meningkat menjadi 70,55.

Hipotesis yang diajukan dalam penelitian ini adalah model discovery learning secara signifikan efektif meningkatkan keterampilan menulis surat dinas siswa kelas VII SMPN Negeri B Srikaton, maka dilakukankan uji statisti dengan menggunakan uji t (uji perbedaan rata-rata). Langkah-langkah yang digunakan dalam teknik analisis data sebagai berikut.

a. Uji Normalitas

Uji normalitas diperlukan untuk mengetahui, apakah data hasil tes siswa berdistribusi normal atau tidak. Kriteria pengujian yang digunakan adalah $\chi^{2}$ hitung dibandingkan dengan $\chi_{\text {tabel }}^{2}$, dengan taraf kepercayaan $5 \%$ dan $\mathrm{dk}=\mathrm{j}-1$, dimana j adalah banyaknya kelas interval. Jika $\chi^{2}$ hitung $\leq \chi^{2}$ tabel maka dapat dinyatakan bahwa data berdistribusi normal, sebaliknya jika $\chi^{2}$ hitung $>\chi^{2}$ tabel maka data tidak berdistribusi normal.

Hasil analisis uji normalitas post test diperoleh harga $\chi^{2}$ hitung $($ chi kuadrat $)=9$, 471. Selanjutnya $\chi_{\text {hitung }}^{2}$ dibandingkan $\chi^{2}$ tabel dengan derajat kebebasan $(\mathrm{dk})=\mathrm{j}$ 1 , dimana j adalah banyaknya kelas interval. Jika $\chi^{2}$ hitung $\leq \chi^{2}$ tabel maka dapat dinyatakan bahwa data berdistribusi normal, sebaliknya jika $\chi^{2}$ hitung $>\chi^{2}$ tabel maka data tidak berdistribusi normal. Nilai $\chi^{2}$ tabel dengan $\alpha=5 \%$ dan $\mathrm{dk}=5$ adalah 11,070. Dengan demikian $\chi^{2}$ hitung $<\chi^{2}$ tabel, maka data berdistribusi normal dan dapat disimpulkan data post test berdistribusi normal.

Tabel 4. Hasil Uji Normalitas

\begin{tabular}{lrrrl}
\hline Variabel & $\chi^{2}{ }_{\text {hitung }}$ & $\mathrm{dk}$ & $\chi_{\text {tabel }}^{2}$ & Kesimpulan \\
\hline Pre-test & 6,775 & 5 & 11.070 & Berdistribusi Normal \\
\hline Post-test & 9,471 & 5 & 11.070 & Berdistribusi Normal \\
\hline
\end{tabular}

Berdasarkan data hasil uji normalitas pada tabel 3 diatas, dengan menggunakan ketentuan uji chi kuadrat $\left(X^{2}\right)$ dapat disimpulkan bahwa masingmasing kelompok data untuk pre test dan post test berdistribusi normal pada taraf kepercayaan $\alpha=0,05$ dan derajat kebebasan $(\mathrm{dk})=5$.

Silampari Bisa: Jurnal Penelitian Pendidikan Bahasa Indonesia, Daerah, dan Asing Vol. 4, No. 2, 2021 


\section{Syahrun Effendi, Eko Saputra}

Efektivitas Model Discovery Learning terhadap Keterampilan Menulis Surat Dinas Siswa Kelas VII SMP Negeri B Srikaton

\section{b. Pengujian Hipotesis (Uji t)}

Berdasarkan hasil uji normalitas data pre test dan data post test dapat dibuktikan bahwa data berdistribusi normal. Dengan demikian, data dilanjutkan dengan uji $\mathbf{t}$. Hasil perhitungan uji $\mathbf{t}$ dapat dilihat pada tabel 5 berikut.

Tabel 5. Hasil Perhitungan Uji t

\begin{tabular}{llcl}
\hline$t_{\text {hitung }}$ & $\mathrm{dk}$ & $t_{\text {tabel }}(5 \%)$ & \multicolumn{2}{c}{ Kesimpulan } \\
\hline 6,683 & $30-1=29$ & 1,699 & $t_{\text {hitung }}>t_{\text {tabel }}$ Ha diterima \\
\hline
\end{tabular}

Berdasarkan tabel 4 hasil uji t di atas dapat diketahui bahwa nilai thitung 6,683 lebih besar daripada tabel 1,699 pada taraf signifikan $5 \%$. Hal itu berarti $\mathrm{H}_{\circ}$ ditolak dan $\mathrm{H}_{a}$ diterima. Dengan demikian, hipotesis penelitian ini dapat diterima kebenarannya, yakni model discovery learning secara signifikan efektif meningkatkan keterampilan menulis surat dinas siswa kelas VII SMP Negeri B Srikaton.

\section{Pembahasan}

Hasil penelitian membuktikan bahwa model pembelajaran discovery learning secara signifikan efektif meningkatkan keterampilan menulis surat dinas siswa kelas VII SMP B Srikaton. Hal ini dibuktikan dengan hasil uji hipotesis bahwa thitung 6,683 lebih besar dari tabel 1,699 pada taraf signifikan $5 \%$. Hasil ini dibuktikan pula oleh perbedaan nilai rata-rata pre test dan post test sebesar 13,45 dimana nilai rata-rata pre test sebesar 57,10 dan nilai rata-rata post test sebesar 70,55.

Kegiatan pre test dilakukan untuk mengetahui kemampuan awal siswa sebelum mengikuti kegiatan belajar mengajar. Hasil analisis nilai pre test diperoleh rata-rata nilai siswa sebesar 57,10 dengan persentase siswa yang tuntas belajar sebesar $13,33 \%$. Pada hasil pre test dapat dinyatakan masih banyak siswa yang mendapatkan nilai di bawah KKM. Dengan demikian dapat disimpulkan bahwa masih banyak siswa yang belum memiliki keterampilan yang baik dalam menulis surat dinas. Mereka masih kurang paham dalam menulis surat dinas.

Harsiati, dkk (2017:248) menyatakan bahwa surat dinas merupakan surat yang ditulis dalam situasi formal dan untuk kepentingan formal. Menurut Syam, dkk (2019:20) surat dinas adalah surat yang berisi masalah kedinasan atau bisnis tertentu yang bersifat resmi. Dalam proses pembuatan surat dinas harus memperhatikan aturan penulisan surat resmi, seperti aturan tata bahasa dan ejaan yang baik dan benar. Maka dari itu, sebelum menulis surat penulis harus mempertimbangkan dengan baik susunan kalimat, pilihan kata, atau diksi, dan ejaan yang dapat memperjelas maksud surat. Selain itu, penulis surat dinas harus menghindari pemakaian diksi yang kurang tepat serta memperhatikan pedoman penulisan surat. Kesalahan dalam berkomunikasi melalui surat dapat dihindari dengan menulis pesan secara jelas serta diungkapkan dengan benar. Penggunaan bahasa yang tepat dan benar dapat membantu penerima surat memahami maksud dari pengirim surat dengan benar 


\section{Syahrun Effendi, Eko Saputra}

Efektivitas Model Discovery Learning terhadap Keterampilan Menulis Surat Dinas Siswa Kelas VII SMP Negeri B Srikaton

Untuk hal itu, maka pada pembelajaran sebagai treatman pertama dilakukan penerapan model pembelajaran discovery learning. Model discovery learning adalah model pembelajaran yang menitikberatkan pada kemampuan mental dan fisik para siswa yang akan memperkuat semangat dan konsentrasi mereka dalam melakukan kegiatan pembelajaran (Rosarina dkk., 2016:374). Melalui pembelajaran discovery learning siswa terlibat dalam penyelidikan suatu hubungan, mengumpulkan data, dan menggunakannya untuk menemukan hukum atau prinsip yang berlaku pada kejadian tersebut. Pembelajaran discovery learning disusun dengan asumsi bahwa observasi yang teliti dan dilakukan dengan hati-hati serta mencari bentuk atau pola dari temuannya akan mengarahkan siswa kepada penemuan hukum-hukum atau prinsip-prinsip (Suprihatiningrum, 2013:242).

Setelah melakukan treatman sebanyak 2 kali pertemuan, dilanjutkan dengan melakukan post test yakni tes akhir kemampuan siswa. Hasil post test adalah nilai rata-rata yang diperoleh siswa sebesar 70,55. Jika dibandingkan dengan nilai tes awal, terdapat perbedaan nilai hasil belajar sebesar 13,45. Walaupun peningkatan nilai hasil belajar siswa dari pre test ke post test tidak terlalu signifikan besarnya, tetapi dapat disimpulkan bahwa keterampilan menulis surat dinas siswa kelas VII SMP Negeri B Srikaton dapat meningkat setelah penerapan model discovery learning.

Berkenaan dengan treatman dalam pembelajaran itu, hasil análisis data dengan rumus statistik uji $t$ diperoleh $t_{\text {hitung }}=6,683$. Selanjutnya hasil thitung dikonsultasi dengan nilai tabel pada daftar distribusi t dengan taraf signifikan $5 \%$ pada derajat kebebasan $\mathrm{dk}=\mathrm{N}-1=30-1=29$. Dengan demikian thitung $(6,683)$ lebih besar daripada $t_{\text {tabel }}(1,699)$ untuk taraf signifikan $5 \%$, hal ini berarti $\mathrm{H}_{\mathrm{o}}$ ditolak dan $\mathrm{H}_{\mathrm{a}}$ diterima. Oleh karena itu, hipotesis yang diajukan dalam penelitian ini dapat diterima kebenarannya, bahwa model discovery learning secara signifikan efektif meningkatkan keterampilan menulis surat dinas siswa kelas VII SMP Negeri B Srikaton. Hasil penelitian ini didukung oleh temuan penelitian selama proses belajar mengajar menggunakan model pembelajaran discovery learning, dalam pembelajaran siswa lebih aktif menemukan sendiri informasi yang diperlukan untuk mencapai tujuan pembelajaran.

Kesimpulan penelitian ini juga sejalan dengan kesimpulan penelitian sebelumnya yang dilakukan oleh Balim (2009) dan Arifani (2016) (dalam Effendi, 2018:19). Balim (2009) membandingkan model discovery learning dengan pembelajaran tradisional dalam pelajaran IPA terhadap dua kelompok siswa kelas 7 tingkat dasar Ismir (Turki) tahun pelajaran 2006/2007. Hasil penelitiannya, model discovery learning efektif diterapkan pada pembelajaran IPA dengan prestasi akademik serta persepsi belajar secara kognitif dan afektif yang lebih baik. Sedangkan hasil Penelitian Tindakan Kelas (PTK) yang dilakukan oleh Arifani (2016) terhadap mahasiswa semester VII Program Studi Pendidikan Bahasa Inggris Universitas Muhammadiyah Gersik membuktikan bahwa penerapan model discovery learning dapat meningkatkan kemapuan mahasiswa dalam menulis proposal skripsi.

Silampari Bisa: Jurnal Penelitian Pendidikan Bahasa Indonesia, Daerah, dan Asing Vol. 4, No. 2, 2021 


\section{Syahrun Effendi, Eko Saputra}

Efektivitas Model Discovery Learning terhadap Keterampilan Menulis Surat Dinas Siswa Kelas VII SMP Negeri B Srikaton

\section{Simpulan}

Berdasarkan hasil penelitian serta pembahasan dapat disimpulkan bahwa model pembelajaran discovery learning secara signifikan efektif meningkatkan keterampilan menulis surat dinas siswa kelas VII SMP Negeri B Srikaton. Hal ini dibuktikan dengan hasil uji hipotesis bahwa pada taraf signifikan 5\% thitung 6,68 lebih besar dari ttabel 1,69. Dengan demikian hipotesis alternatif $(\mathrm{Ha})$ penelitian ini kebenarannya diterima.

Berdasarkan hasil penelitian ini diharapkan guru bahasa Indonesia dapat menerapkan model pembelajaran discovery learning untuk memperbaiki dan meningkatkan kemampuan belajara siswa, khususnya dalam meningkatkan kompetensi menulis surat dinas. Selain itu, model pembelajaran discovery learning dapat juga diterapkan pada pembelajaran kompetensi dasar yang sekarakteristik, khususnya dalam pembelajaran menulis surat dinas.

\section{Daftar Pustaka}

Ahyana. (2020). Kemampuan Menulis Surat Dinas Siswa Kelas VII B SMP Negeri 12 Palu. Jurnal Bahasa dan Sastra, 5(3), 3.

Arifani, Y. (2016). The Implementation of Team-Based Discovery Learning to Improve Students' Ability in Writing Research Proposal. International Education Studies, 9(2), 111.

Arikunto, S. (2010). Prosedur Penelitian Suatu Pendekatan Praktik. Jakarta: PT Rineka Cipta.

Azhari, (2015). Penerapan Model Pembelajaran Discovery Learning terhadap Peningkatan Hasil Belajar Siswa Kelas XI-IPA1 pada Materi Sistem Penerapan di SMA Negeri Unggul Sigli. Jurnal Biologi Edukasi, 7(1), 15.

Balim, A. G. 2009. The Effects of Discovery Learning on Students' Succes and Inqury Learning Skills. Eurasian Journal of Educational Research, 9(35), 117.

Effendi, M. S. (2018). Pengaruh Model Pembelajaran dan Kemampuan Bernalar terhadap Kemampuan Menulis (Penelitian Eksperimen pada Siswa Kelas IV SD Ogan Ilir-Sumatera Selatan yang Melaksanakan Kurikulum 2013). Disertasi Pendidikan Bahasa Universitas Negeri Jakarta.

Harsiati, T., Trianto, A., \& Kosasih, E. (2017). Bahasa Indonesia. Jakarta: PT Gramedia.

Nurgiyantoro, B. (2012). Penilaian Pembelajaran Bahasa Berbasis Kompetensi. Yogyakarta: BPFE-Yogyakarta.

Silampari Bisa: Jurnal Penelitian Pendidikan Bahasa Indonesia, Daerah, dan Asing Vol. 4, No. 2, 2021 


\section{Syahrun Effendi, Eko Saputra}

Efektivitas Model Discovery Learning terhadap Keterampilan Menulis Surat Dinas Siswa Kelas VII SMP Negeri B Srikaton

Permatasari, S. E. (2019). Kohesi dan Koherensi pada Surat Dinas di Kantor Dinas Pendidikan dan Kebudayaan Kota Praumulih. Journal of Language Learning and Research (JOLLAR), 2(2), 41-54. doi:10.22236/jollar.v3i2.5771

Pratiwi, D. P. (2020). Keefektifan Model Discovery Learning Berbantuan Audiovisual terhadap Hasil Belajar IPS Kelas IV. Joyful Learning Journal, 9(3), 133-137. doi:10.15294/jlj.v9i3.39705

Rosarina, G., Sudin, A., Sujana, A. (2016). Penerapan Model Discovery Learning untuk Meningkatkan Hasil Belajar Siswa pada Materi Perubahan Wujud Benda. Jurnal Pena IImiah, 1(1), 374.

Salmi. (2019). Penerapan Model Pembelajaran Discovery Learning dalam Meningkatkan Hasil Belajar Ekonomi Peserta Didik Kelas XII IPS.2 SMA Negeri 13 Palembang. Jurnal Profit, 6(1), 6.

Suprihatiningrum, J. (2013). Strategi Pembelajaran. Yogyakarta: Ar-ruzz Media.

Syam, S., Komalasari, D., Yurfiah. (2019). Pelatihan Penulisan Surat Dinas di Desa Lanto Kecamatan Mawasangka Tengah Kabupaten Buton Tengah. Jurnal Pengabdian Kepada Masyarakat, 3(2), 20.

Wiguna, M. Z., Ramaniyar, E., Kusnita, S. (2016). Analisis Bentuk Surat Dinas Program Studi Pendidikan Bahasa dan Sastra Indonesia Tahun Akademik 2013/2014 Semester Genap. Jurnal Edukasi, 14(1), 96.

Wiguno, P. S., \& Jaja, J. (2019). Pengembangan Bahan Ajar Teks Surat Berdasarkan Surat Pribadi dan Surat Dinas dan Implementasinya dalam Pembelajaran di SMP. Jurnal Tuturan, 8(2). doi:10.33603/jt.v8i2.2868

Yuliana, N. (2018). Penggunaan Model Pembelajaran Discovery Learning dalam Peningkatan Hasil Belajar Siswa di Sekolah Dasar. Jurnal IImial Pendidikan dan Pembelajaran, 2(1), 22-23.

Silampari Bisa: Jurnal Penelitian Pendidikan Bahasa Indonesia, Daerah, dan Asing Vol. 4, No. 2, 2021 